\title{
Modeling South African Accounting Academic Staff Teaching Rationalism Factors for the Preservation of Indigenous Knowledge
}

\author{
Zwelihle Wiseman Nzuza \\ Durban University of Technology, Durban, South Africa \\ zwelihlen@dut.ac.za
}

\begin{abstract}
South African universities are under pressure to maximize the amount of accounting students, with specific reference to expand the number of qualified black African accountants, especially the Chartered Global Management Accountants (CGMA). Accountants are at the center of countries' economy and act as lecturers in the academic institutions. Therefore, the issue of inadequate production of a new brand black qualified accountants may have something to do with accounting academic staff teaching rationalism, and this study seeks to address that subject. Literature has been used to investigate factors influencing accounting academic staff teaching rationalism and to propose a suitable model for accounting academic staff teaching rationalism factors for the preservation of South African indigenous knowledge. The proposed model forms the basis of the study results and is grounded on sound perception theories: bottom-up theory and top-down theory. The significance of a proposed model is subject to experiments by other scholars within the boundaries of the republic of South Africa or even outside.
\end{abstract}

Keywords: Accounting theories, teaching accounting rationalism factors, history of accounting

\section{Introduction}

South African universities' Act No. 84 of 1996, maintains that proper education is ... necessary to transform the society for the better and to contest racialism, sexism and other forms of prejudiced judgement. In this regard, the Constitution of South Africa, Act No. 108 of 1996 spots out central values that has to be taken into account in the manner that universities should function (Unerman \& O'Dwyer, 2010). This means that South Africa is in need of good academic staff that is willing to carryout great teaching and learning assignments for the better. Lubbe (2013: 110) this need is most evident in the accounting discipline since there are shortages of qualified accountants than expected. These include CGMA, Professional Accountants of South Africa (PASA), Chartered Accountants of South Africa (CASA), Association of Chartered Certified Accountants (ACCA) and many more. Even though these are professional bodies operating independently of the universities, but the fact is that universities are the first institutions to academically qualify individuals whom are willing to pursue any of these above mentioned professions. The shortage of qualified accountants in the country can therefore be a question of accounting academics in the universities. In support of this, preceding scholars (Lubbe, 2013: 110; Pouris, 2012: 30; ICAA, 2011; Unerman \& O'Dwyer, 2010; Albrecht and Sack, 2000) have highlighted common factors that are crippling the process of teaching and learning in accounting such as the notion that new accounting knowledge is not created in the university, but rather in businesses or professional bodies; it is hard to accurately describe the occupational work of accountants in the corporate world; accounting communities believe that several real matters of accounting do not require new knowledge; accountants perceive themselves as meek, impersonal, boring, unattractive, independent, conservative, meticulous and unimaginative.

As a result, the study by Pouris (2012: 30) found that accounting academics, most of whom have accounting degrees, indicated to not major with accounting if pursuing their education over again. The author also found that academic accountants are influenced by the long term earnings, job market conditions than a genuine interest in teaching and learning. This study will however not focus on the learning aspect but on accounting academic teaching rationalism. This is because literature that seeks to explore accounting academic teaching rationalism have not been explored yet there is evidence of poor quality of accounting graduates being produced by the universities. Due to limited resources, this study seeks to fill this gap by modeling a theoretical framework for accounting academic staff teaching rationalism factors for the preservation of 
indigenous knowledge, with specific reference South Africa. According to Ngcobo \& Eyono Obono (2013: 223), indigenous knowledge speaks of interpretations, theories, regulations, norms, and language, which are instinctive to a local community, and are entrenched in the minds of local accounting users. Preservation of indigenous knowledge in accounting carries a lot of benefits such as to recover understanding of basic lost concepts; increase awareness to users and practitioners; building on local experiences, and retain sense of ownership.

Aim and objectives: The aim of this study is to design a South African accounting academic staff teaching rationalism factors model for the preservation of indigenous knowledge. The two main objectives of this research are to investigate the factors influencing accounting academic staff teaching rationalism and to develop a South African model for accounting academic staff teaching rationalism factors. The proposed model will be only applicable to the South African universities.

Theoretical framework: Accounting academic staff teaching rationalism is influenced by the perception that they have about accounting as a career. In a process of acquiring and processing of information, literature reveals two available theories of explanations of perception according to the direction of information flow. The first one is bottom-up direct perception theories which represent processes that begin at the deepest sensory levels and then they slowly lead to more intricate and complex processes. The second theories are top-down indirect perception theories. Top-down theories favor direct perception without involvement of knowledge and previous experience ... perception is likely only by means of computation of rational picture of a given reality. Top-down theories include constructivist theories, Gregory's theory, computational theories such as Marr's model of perception, and Synthesizing theories such as Neisser's analysis-by-synthesis model (Demath, 2013: 23-33). In constructivist theories, perception serves as the end point and cornerstone of the interface between motivation and internal assumptions. Perception is thus prejudiced by extensive array of separable factors that can lead to an inadequate elucidation (Eysenck \& Keane, 2008: 74). In order to achieve a primary objective of the study, the researcher used both the Gibson's theory of direct perception and Gregory's theory. This is because Gibson's theory believes that rational apparatus of accounting academic staff is created and formed by long evolutionary impacts of external environment which is misleading in its approach. Gregory's theory on the other hand believes that the perception of accounting academic staff is based on their previous experiences, which makes it possible for them to be thinking about the future while still thinking about the past (Gregory, 1990: 219). The combination of these two theories helped to consider both the internal and external issues when modeling the South African accounting academic staff teaching rationalism factors for the preservation of indigenous knowledge.

\section{Literature Review}

Accounting definition: For the purpose of this study, it is important that we start by defining the term 'accounting'. This study will use existing accounting definitions on the basis of acceptance by the accounting scholars. It is not the intention of this study to critique any of these definitions but the study seeks to model accounting academic staff teaching rationalism factors. The American Institute of Certified Public Accountants (AICPA) defines accounting as "the art of recording, classifying and summarizing in a significant manner and in terms of money, transactions and events which are in part at least, of a financial character, and interpreting the results thereof" (Belkaoui, 1992: 22). Lodewyckx, Lotter, Rhodes \& Seedat (2013: 2) define accounting as a systematic way of recoding and explaining a situation which involves money. Accounting can also be regarded as a language used by accountants to communicate amongst them including any other interested parties called 'users'. However, accounting language is used depending on which country the information is shared. This is because other countries would require that the accounting information is shared using their respective general accepted accounting practice (GAAP), whereas others would require that it is shared in international GAAP called 'International Financial Reporting Standards (IFRS) (Service, 2016: 4).

\section{Historical development of accounting}

International development: Accounting development played a big in the world economy including numbers and money and it has come up with a double entry bookkeeping system that can be traced back in the Italian history (Anderson-Gough, Grey \& Robinson, 1998). Furthermore, historians are of the opinion that the first 
accounting institution was established in 1581 in Boudqua city, and that the second profound historical development of accounting (double entries, trading and evolutions) were discovered in 1495 to 1800 . The first discovery record of a broad double-entry system remains the Italian Messari accounts of the Republic of Genoa in 1340 (Schroeder, Clark \& Cathey, 2001). As the result, many businesses like the investors and merchants of Florence, Genoa, Venice and Lubeck they started using the double-entry bookkeeping system widely. Another earliest profound evidence of full double-entry bookkeeping is the Farolfi ledger of 18011955. Literature reveals that the double entry system was pioneered and remains to be the work of an Italian Monk, and a Franciscan friar, in 1494, and was further developed by Luca Pacioli. Pacioli's first printed work was on algebra, titled: "Summa de Arithmatica, Geometrica, Proportioni et proportionality (i.e. everything about Mathematics, geometry, and proportions)". The double entry system seeks to balance the two sides of the accounting equation (Mike and Fred, 1983). The work contained a section on book keeping entitled "De computis or Scripturis (i.e.computations and records) which was separately published in 1504 and translated into many languages". Pacioli in his articles was not the originator of double entry but he seeks to describe what Italian Merchants were using for over 200 years (Paton \& Littleton, 1940 as cited by Angus, 2014: 4).

Other historians of accounting history like Keistar (1965) \& Chatfield (1977) divulge that Mesopotamia is the historical source of most ancient cities that had developed accounting, and is known as a home of number between 450 and $500 \mathrm{BC}$. In about $630 \mathrm{BC}$, Greece and Rome cities invented coinage to be used instead of exchanging goods for goods. China on the other hand, was concerned with the recording of merchant, temples, and estates (Angus, 2014: 3). The early Greeks and Rome accounts were kept on the basis of "charge" and "discharge" principle which is known as receipt and payment account today (James, 1955). Even though the notion of income and return on capital invested were missing under these principles, but the charge and discharge syndrome had been used for a long period of time, lasting from $12^{\text {th }}$ to $19^{\text {th }}$ centuries. Another memorable and profound work performed by Italian Monk-Luca Pacioli from England was that of linking the double entry bookkeeping system for merchants with the charge and discharge systems (James, 1955 as cited by Angus, 2014: 4). According to Oldroyd \& Dobie (1917: 99), prior 1801 to 1955, before Queen Elizabeth II reigns, the British East India Company had no legal right to trade with countries in the east of the Cape of Good Hope. Most United Kingdom (UK) corporations were in essence reliant on the British navy's capacity to governor trade paths with its robust auditing and accounting. In the case of Colonial America prior to 1890 s, the terms bookkeeping and accounting were not used consistently because their computation system was central to chronological transactions, and the accounting records were very basic for that matter (Mohamud \& Hikmat, 2013: 98-99).

Accounting in South Africa: Following the South African mines discovery on the Witwatersrand in 1886 by the British society from England and Wales, the British established the first organized institute of chartered accountants which was officially launched in 1894 in Johannesburg with 65 foreign members (SAICA history, 2015). The institute was officially given name "South African Institute of Chartered Accountants" (SAICA). During which time, the society of SAICA and auditors in South Africa had many colonial and foreign members and has always been a leading profession in accountancy around the world (Lubbe, 2013: 110).

International accounting standards: Accounting standards are the composites of assumptions, doctrines, principles, rules, laws, and theories for practicing accounting. June 1973, marks as the historical development of the accounting standards by International Accounting Standards Committee (IASC) and it was afforded to be officially released in year 2000 when the International Accounting Standards (IASs) gained full recognition by various Stock Exchanges around the world (ICAEW, 2011). IASC had developed not more than 41 global accounting standards. In 2001, IASC was replaced by the International Accounting Standards Board (IASB). At that time, IASB announced a new number of series for the accounting standards. The International Accounting Standards is now known as International Financial Reporting Standards (IFRS) and there are 13 of them developed recently by IASB in exchange of 12 of the older standards (IAS's). This means that, as at 2016, there are 29 accounting older standards in operation plus 13 new standards, totaling to 42 IFRSs (Service, 2016: 7). Accounting standards is looked after by four accounting structures namely, the standing interpretations committee (SIC), exposure drafts (ED) and letter of intent (LOI), monitoring board, and IFRS advisory council. SIC provides authoritative guidance over interpretations of standards. ED and LOI allow accounting communities all over the world to first conduct their respective studies on how accounting is being used and ultimately come up with collective findings on how accounting should be improved (Mootze, 
1970: 155). Monitoring board's objectives and responsibilities as defined in its cheater is to ensure that the trustees perform their duties of the IFRS foundation as prescribed in the IFRS foundation constitution and to approve the appointment of trustees (IFRS, 2011). IFRS advisory council is involved in developing standards and to advise the IASB on various matters (Deloitte Touche Tohmastu Limited, 2011).

Accounting theories: Most accounting practitioners they are at variance with accounting scholars if whether the basis of accounting are both application and theory or is only application not theory or either way. As the results, research has not gained a momentum in the accounting field. Nevertheless, there are a lot of theories that have been developed in accounting for both practitioners and academic use. Following are some of these theories.

Descriptive accounting theory:Descriptive accounting theory is concerned with judging whether accountants make rational or irrational decisions. These theories are, for example, regret theory and prospect theory for they can predict how an event will be treated in accounting from the start to the end. Descriptive regret theory was simultaneously pioneered by Bell, Fishburn, Loomes \& Sugden. According to Schroeder, Clark \& Cathey (2001), it uniqueness remains that it omits the assumption of preferences transitivity. Prospect theory on the other hand which is also called cumulative prospect theory was first put forward by Daniel Kahneman \& Amos Tversky in 1979. The theory is deliberated for decision making under risk from the point of view of traditional behavioral sciences (Glautier \& Underdown, 1991).

Normative accounting theory: Normative accounting theory is an advice in nature. Its purpose is to express, how accountants should act when they are confronting a challenge of taking a risky decisions. Basically, it is mainly focused in advancing the future with the present available resources (Belkaoui, 1992).

Evaluative accounting theory: Evaluative accounting theory quantifies the qualitative quantity of the accounting event concerned and seeks to inform the accounting users about the quantity and quality of any event (Mootze, 1970:156).

Communicative accounting theory: Communicative accounting theory puts up with the future forecast of accounting events. The theory is messaging in nature so that accountants can get ready for any future event if they have the knowledge of communicative theory (Mootze, 1970: 149).

Inductive accounting theory: Inductive accounting theory helps accountants to critically analyze the happenings of past accounting events. In other words, it is based on frequent accounting events and informs accountants that once beaten twice shy (Singmann \& Klauer, 2011: 283).

Deductive accounting theory: Deductive accounting theory is equipped by following the method of reasoning. The theory is meant to show accountants the way in which they must behave. For example, if all accountants are human beings, all human beings make mistakes; therefore all accountants ought to make mistakes (Mootze, 1970: 149-156 and Singmann \& Klauer, 2011: 283).

Generally accepted accounting theories: All of the above mentioned approaches are regarded as philosophical theories in accounting. Besides the above mentioned theories, there are other theories (too many to mention) which are also in existence and can be applied equally in all cases as shown above and are generally adopted by accountants, and therefore are called generally accepted accounting theories (Singmann \& Klauer, 2011: 283).

Primary responsibility of accounting academics: The primary tasks of accounting academic by van der Schyf (2008: 11) can be described in terms of three Worlds (W): W1, W2 and W3. W1 consists of wise sayings; common sense; practicality; how to do; or what may termed rational knowledge. It consists of the "social", "physical" and symbol words in which accounting academics operate. W2 is the result of W1 observation. This phenomena can be political, economic, social, physical or in any other form. In short, W2 represents the "World of accounting as a social science and scientific research in accounting", including academic activity in accounting. The main rudiments of W2 are the, theoretical foundations of accounting, accountancy concepts and definitions, and research. W3 represent the "World of meta-science" where critical 
reflection and assignment occurs. It is a position where the accounting academics reflect on the knowledge in W2 (scientific world). In W3, the accounting academics collectively examine the presentations within the scientific world and place these in congruent, comprehensible wholes which are also referred to as epistemology and ontology. The three worlds are a critical role players in accounting education recurriculation, teaching pedagogy, modernization, and in innovation of all parts of accounting (Pouris, 2012: 2$6)$.

What is meant by accounting teaching? Accounting teaching can be defined as a way that embraces various techniques used to convey accounting knowledge from one person to another. Authors are of the view that teaching should relate to pedagogic approach that promotes active learning (Kalpana, 2014: 28; as cited by Carla \& Phillip, 2014: 52). Effective teaching of accounting should balance between theory and practice. Like in science, accounting can be proved as write or wrong. For example, a debit and a credit principle in accounting result to total assets = owners' equity + liabilities. This equation is applied consistently by both the academics and practitioners. This advocates that accounting teachers must be able to construct students' knowledge out of their capabilities.

Common teaching methods in accounting: The commonly used teaching methods in accounting are broadly explained below:

Videotapes/computer: This is an automated video technique and is commonly used in classrooms for teaching accounting. This method looks professional and it helps to keep groups' attention and can inspires groups' dialog after a lecture (University of Mexico School of medicine, 2014: 1).

Brainstorming: This method requires that audience should pay full attention and listen attentively so as to exercise creativity thinking thereafter. The success of this method demands that a teacher must have new ideas for the students' in order to stimulate their thinking capacity otherwise students may fail to acquire new knowledge (University of Mexico School of medicine, 2014: 1).

Discussions: This kind of learning may take place after lecture when seeking for clarify or challenging what was taught in class (Hill, 2002: 8-10). The method also pools ideas and experiences from groups that are formed by a maximum of 20 students per group. Even though the method allows for a consensus, but the larger the number of individuals per group, the difficulty it is for everyone to participate in the group. Due to time constraint, this method may not be effective as it was intended. (HEC, 2012:14)

Panel of experts: This method allows more than one experts to voice their opinions. The method can provoke a group discussion than a one on one discussion. The success of this method demands that the panel must have good speakers in order to have innovative discussion (HEC, 2012: 7).

Worksheets: Worksheets method can be also referred to as surveys. This type of a teaching method allows students to work independently but is also flexible for sharing information (HEC, 2012: 17).

Lecture presentation: Lecturing is a type of a higher leaning teaching method that is presented in a logical manner. Experience is used in balancing the theory with reality (University of Mexico School of medicine, 2014: 3).

Case studies: Case studies can be used to advance students logical thinking and ultimately problem solving expertise. It allows for examination of responses for intricate subjects, and permits students to relate new knowledge and expertise. The impact of this method to students depends on the relevance of the situations used in the case study scenario (University of Mexico School of medicine, 2014: 1).

Role playing: Role playing method presents difficult position vividly and offers students the prospect to exercise the subject skills (Hill, 2002: 19-20).

Report-back sessions: This method permits for big group debates and small group debates by giving those equal chances to replicate on past experiences (University of Mexico School of medicine, 2014: 7). 


\section{Factors affecting teaching accounting in the classrooms}

Known reality: Little is known about the ways in which accounting academic staff as individual professionals develop and sustain their own personal and professional knowledge (Unerman \& O'Dwyer, 2010). But in generally, accountants consider that universities are unable to invent new accounting knowledge, rather in commercial sectors or professional bodies (Lubbe, 2013: 110). Carla \& Phillip (2014: 49-50) the attitude of accountants either practitioners or academics is influenced by factors like long term earnings and job market conditions. They also perceive themselves as meek, impersonal, boring, unattractive, independent, conservative, meticulous and unimaginative (Albrecht \& Sack, 2000). Their personality is closely linked to the $20^{\text {th }}$ centuries where most people from commercial sectors including public sector organizations were referred to as accountants' regardless of accounting qualifications. This was merely because there were not many developments in accounting and, after all, those who pretended to have good accounting knowledge had found it difficult as there were less information and other related resources. Basically, their education levels of that time had no broad accounting knowledge (Unerman \& O’Dwyer, 2010).

Educational facilities: Existing facilities in the classroom like teaching media, teaching aids or any other useful facility affect teaching in the classroom. With the existence of adequate facilities, it will be very easy for teachers to provide an innovative learning system (Carla \& Phillip, 2014: 51-52).

Teaching method: When teaching accounting subjects, lectures should use relevant methods that can provide the opportunity for students to solve given problems. In this way, a lecturer's attitude towards teaching accounting will be positive because of a kind of students produced who are active and critical thinkers. If the lecturer's psychology is good, and then his teaching rationalism is going to get maximum results (Unerman \& O’Dwyer, 2010).

Context of culture and syllabi: Accounting culture has a resilient impact on individual lecturers teaching rationalism. Accounting culture may include its historical development, theories, and standards interpretation. The relevance of accounting to the needs of the society is also influential on the lectures teaching rationalism (Mohamud \& Hikmat, 2013: 99).

\section{Methodology}

The research design of this study is largely grounded on the primary findings and has assisted to identify accounting academic staff teaching rationalism factors in both private and public universities.

Limitations of the study: Even though the researcher used all available literature, but a proposed model is only applicable to the South African universities and cannot be generalized to other universities outside the country.

\section{Results}

This section presents the suitability of the above cited variables in the accounting academic staff teaching rationalism framework.

Modelling accounting academic staff teaching rationalism factors: When using both the Gibson's theory of direct perception and Gregory's theory for modelling the accounting academic staff teaching rationalism factors, it became clear that accounting academics are strongly influenced by the bottom-up and top-down factors in teaching accounting aspects. This means that teaching accounting is solemnly driven by the lecturer's known reality/perception, educational facilities, accounting culture, and professional body requirements. The results of this study are displayed in figure 1. 
Figure 1: Proposed accounting academic staff teaching rationalism factors model

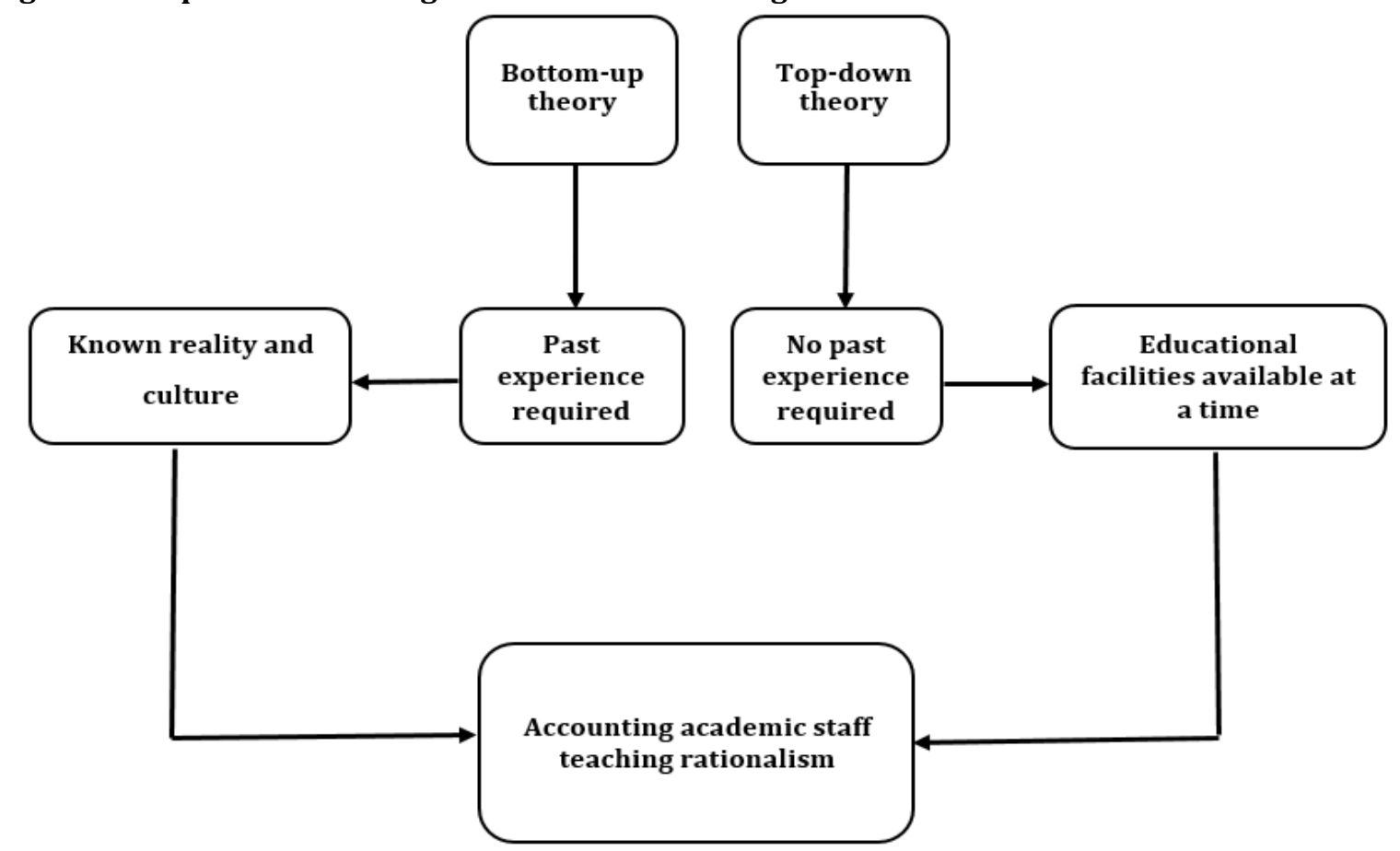

Source: Self-developed

Known reality - Believe that accounting academics are aware that their teaching models cannot change accounting principles or make any amendments since accounting is an international focused subject.

Accounting culture - Believe that accounting academics are aware that accounting has theories, principles, interpretations and standards that are internationally recognized and that no one can change or adjust expect by the international bodies.

Educational facilities - Believe that accounting academics are convinced by what they see at a given time. For example, their present moment is influenced by teaching facilities and type of audience that they are dealing with at a given time.

\section{Discussion, conclusion and recommendations}

The reviews of existing accounting theories and teaching theories were conducted followed by a review of accounting academic staff teaching rationalism factors. The accounting academic staff teaching rationalism factors were then matched to identify the best model. As far as the findings of this study are concern, the bottom-up theory and top-down theory are the best two phenomena for modelling accounting academic staff teaching rationalism factors. This research provided sub-beliefs under each theory. For example, bottom-up theory (which requires pas experience) gave birth to known reality and culture factors which were then expanded with other three sub-beliefs: (1) cannot change accounting principles, (2) difficulty to make amendments, (3) and is international focused. Top-down theory (which requires no experience) gave birth to a factor called 'educational facility' which was also expanded with two other sub-beliefs: (1) teaching facilities, (2), and type of audience. The main contribution of this paper resides in the fact that it provides literature based model of the factors influencing accounting academic staff teaching rationalism. Future researches are encouraged to empirically validate a theoretical model proposed by this paper.

\section{References}

Albrecht, W. S. \& Sack, R. J. (2000). Accounting education: Charting the course through a perilous future, American accounting association, accounting education series, 16. Available WWW http://aaahq.org/pubs/aesv16/toc.htm(Accessed 9 June 2016). 
Association of Chartered Certified Accountants. (2001). Available WWW: http://www.sacob.com/courses/institutions/association-of-chartered-certified-accountants (Accessed 11 July 2015).

Angus, O. U. (2014). Theories of accounting: Evolution \& developments, Income-determination and diversities in use. Research Journal of Finance and Accounting, 5(19), 1-4.

Belkaoui, A. (1992). Accounting theory. $13^{\text {th }}$ ed. London: Dryden Press

Carla, L. W. \& Phillip, A. C. (2014). A problem-based approach to accounting education: A pragmatic appraisal of a technologically enabled solution. International journal of education and development using information and communication technology, 5(2), 49-52.

Deloitte ToucheTohmastu Limited. (2011). IAS Plus - User of IFRS by jurisdiction - domestic listed and unlisted companies. Available www: http://www.iasplus.com/country/useias.htm (Accessed 9-5-15).

Demath, A. (2013). Perception Theories. Available WW: http://fff.truni.sk/userdata/ebooks/demuth_perception_theories\%20(1.1).pdf. (Accessed 16 August 2016).

Eysenck, M. W. \& Keane, M. T. (2008). Kognitivnipsychologie. Praha: Academia.

Glautier, M. W. E. \& Underdown, B. (1991). Accounting Theory and Practice. $4^{\text {th }}$ ed. London: Pitman Publishing.

Gregory, R. L. (1990). The evolution of eyes and brains - a hen-and-egg problem. The neuropsychology of Spatially Orientated Behavior. Illinois, 2, 219.

Higher Education Commission. (2012). Methods of teaching: Course guide. Available WWW: http://www.hec.gov.pk/insidehec/divisions/learninginnovation/documents/learning\%20portal/nh e\%20(presesation)/common\%20teaching\%20methods.pdf. (Accessed 9 June 2016).

Hill, L. (2002). Module 7.2 general teaching methods. Available WWW: http://education.gov.pg/TISER/documents/pastep/pd-tm-7-2-general-teaching-methods student.pdf. (Accessed 9 June 2016).

Lodewyckx, E., Lotter, W., Rhodes, N. \& Seedat, C. (2013). Introduction to financial accounting: Fresh perspectives. $\quad 2^{\text {nd }}$ ed. Cape Town: Juanita Pratt.

Lubbe, I. (2013). Educating accounting professionals: Development of a theoretical framework as a language of description of accounting knowledge production and its implications for accounting academics at South African universities. South African Journal of Accounting Research, 27(1), 110.

Mike, H. \& Fred, K. (1983). Financial accounting theory and standards. $2^{\text {nd }}$ ed. Great Britain, Prentice Hall International, Inc.

Mohamud, A. \& Hikmat, A. A. (2013). The development of accounting through the history. International journal of advances in management and economics, 2(2), 98-99.

Mootze, M. (1970). Three contributions to the development of accounting principles prior to 1930. Journal of accounting research, 8(1) 149-156.

Ngcobo, K. M. \& Eyono-Obono, S. D. (2013). Modeling ICT adoption factors for the preservation of indigenous knowledge. International journal of social, behavioral, educational, economic, business and industrial engineering, 7(1), 223.

Oldroyd, D. \& Dobie, A. (1917). Themes in the history of bookkeeping, the rout ledge companion to accounting history. London journal, 1(2), 96.

Pouris, A. (2012). Science in South Africa: The dawn of a renaissance? Available www: http://www.sajs.co.za/sites/default/files/publications/pdf/1018-9192-12-PB.pdf. (Accessed 9-6-16).

Service, C. L. (2016). Gripping GAAP. Your guide to international financial reporting standards. $16^{\text {th }}$ ed. Pietermaritzburg: LexisNexis.

Schroeder, R., Clark, M. \& Cathey, J. (2001). Financial accounting theory and analysis: Text readings and cases. $7^{\text {th }}$ ed. London: John Wiley \& Sons Inc.

Singmann, H. \& Klauer, K. C. (2011). Deductive and inductive conditional inferences: Two modes of reasoning. Thinking \& reasoning, 17(3), 283-284.

Unerman, J. \& O'Dwyer, B. (2010). The relevance and utility of leading accounting research, ACCA, London.

University of Mexico School of medicine. (2014). Teaching strategies/methodologies: Advantages, disadvantages/cautions, keys to success. Available www: http://tulane.edu /some/upload/ComparisonOfTeachingMethodologies.pdf. (Accessed 9 June 2016).

Van Der Schyf, D. B. (2008). The essence of a university and scholarly activity in accounting, with reference to a department of accounting at a South African university. Meditari accountancy research, 16(1), 1819. 